\title{
Maturation of rabbit follicular oocytes in a defined medium of varied osmolality
}

\author{
I.-H. Bae* and R. H. Foote \\ Department of Animal Science and Division of Biological Sciences, Cornell University, Ithaca, \\ New York 14853, U.S.A.
}

\begin{abstract}
Summary. Rabbit oocytes from follicles $\geq 1 \mathrm{~mm}$ in diameter were cultured for $18 \mathrm{~h}$ in a defined medium with osmolality adjusted in 20 mosmol increments from 230 to 350 mosmol by altering only the $\mathrm{NaCl}$ concentration. Adjustment, based upon determination of the osmolality of the medium, was necessary because a difference existed between calculated and achieved osmolality in this complex solution. The proportions of oocytes which matured to meiosis II with polar body formation were $64,68,64$ and $65 \%$ in media of $250,270,290$ and 310 mosmol, respectively.
\end{abstract}

\section{Introduction}

It is important to provide optimum conditions when using in-vitro culture techniques. Media are often formulated with an osmotic pressure of 308 mosmol, approximately equivalent to that of body fluids (Brinster, 1965a). However, it has been reported that the optimum osmolality of culture media for mouse embryos (Brinster, 1965a, b) or mouse oocytes (Cross \& Brinster, 1970 ) is lower than accepted physiological levels. Similar findings resulted from studies in which salt and nutrient requirements were established for hamster (Gwatkin \& Haidri, 1973) and pig (McGaughey, 1977) oocytes. Bae \& Foote (1975) reported that rabbit follicular oocytes could be cultured successfully in a carbohydrate-free defined medium with an osmolality of 308 mosmol, compared to the value of 270 mosmol previously considered to be optimal for 2- and 4cell rabbit embryos (Naglee, Maurer \& Foote, 1969). The purpose of the present study was to evaluate further the defined medium used for successful culture of rabbit oocytes and to establish the salt concentration which would promote the highest proportion of oocytes to mature, while minimizing the occurrence of anomalies.

\section{Materials and Methods}

Animals and experimental design. Virgin Dutch belted rabbits 4-7 months old were killed by cervical dislocation to avoid possible effects of anaesthesia on the oocytes. Sufficient donors were killed at each time to provide a pool of oocytes for distribution to all the test media. Data from the 7 replicates performed were homogeneous and were pooled and subjected to analysis of variance, and the significance of differences among treatment means was determined by Tukey's w procedure (Steel \& Torrie, 1960).

Oocyte recovery. The ovaries were removed immediately and washed 3 times in medium (see below) without glutamine and containing only $0.1 \%(\mathrm{w} / \mathrm{v})$ bovine serum albumin (BSA).

- Present address: Department of Biology, Sungshin Women's Teachers College, Seoul 132, Korea. 
Ovaries were transferred to the same type of medium under mineral oil and oocytes were recovered from follicles $>1.0 \mathrm{~mm}$ in diameter. Repeated aspiration through a finely drawn pipette removed most of the mucous layer and a few cumulus cells. Oocytes were washed rapidly 3 more times in the same medium and pooled. Only oocytes which were judged to be normal in appearance were cultured.

Culture medium. Concentration of the $\mathrm{NaCl}$ was varied from 4.63 to $8.14 \mathrm{~g} / 1$ to achieve the various osmolal concentrations of 230 to 350 mosmol. Other components in $\mathrm{g} / \mathrm{l}$ were: $\mathrm{KCl}$, $0.356 ; \mathrm{CaCl}_{2} \cdot 2 \mathrm{H}_{2} \mathrm{O}, 0.256 ; \mathrm{KH}_{2} \mathrm{PO}_{4}, 0.162 ; \mathrm{MgSO}_{4} \cdot 7 \mathrm{H}_{2} \mathrm{O}, 0.293 ; \mathrm{NaHCO}_{3}, 2 \cdot 106 ;$ glutamine, 0.292 ; bovine serum albumin, 4.00, plus 100000 Units of penicillin $\mathrm{G} / \mathrm{l}$ and $50 \mathrm{mg}$ streptomycin/l. All of the components except $\mathrm{NaHCO}_{3}$, glutamine and BSA were dissolved together in advance, in water twice-distilled through glass. Just before use, $\mathrm{NaHCO}_{3}$, glutamine and BSA were added to the medium in that order, and the osmolality was checked with an osmometer (Advanced Instruments, Inc., Newtown Highlands, Massachusetts, U.S.A.). Despite careful preparation, the measured and the calculated osmolality of the various solutions differed by $0-25$ mosmol. All media were adjusted to within 5 mosmol of the planned concentration. The medium was saturated with $\mathrm{CO}_{2}$, sterilized by passage through a $0.45 \mu \mathrm{m}$ diameter millipore filter, and kept in tightly closed vials during use. The $\mathrm{pH}$ was maintained at $7 \cdot 2 \pm 0 \cdot 1$.

Culture and evaluation of oocytes. Oocytes were distributed randomly to the various media and cultured under mineral oil for $18 \mathrm{~h}$ at $37^{\circ} \mathrm{C}$ in $5 \% \mathrm{CO}_{2}$ and $95 \%$ air in an humidified atmosphere (Bae \& Foote, 1975). Oocytes were fixed and stained with acetic-lacmoid and examined for chromosomal arrangement, polar body formation and general appearance.

\section{Results and Discussion}

The results for oocyte development are given in Table 1. The highest proportion of oocytes developing to meiosis II, and showing polar bodies, was $68 \%$ in the 270 mosmol medium. This mosmol value is similar to those reported as optimal for pig oocytes, 285 mosmol (McGaughey, 1977), for hamster oocytes, 285-295 mosmol (Gwatkin \& Haidri, 1973), 2-cell mouse embryos, 276 mosmol (Brinster, 1965a), and 2- to 4-cell rabbit embryos, $270 \mathrm{mosmol}$ (Naglee et al., 1969). The optimum osmolality of culture solutions for oocytes and young embryos, at least for these species, is therefore less than that of blood serum. One possible explanation is that the concentration of macromolecular components is usually lower in defined media than in body

Table 1. Effect of varied osmolality on development of cultured follicular oocytes of rabbits

\begin{tabular}{|c|c|c|c|c|c|c|c|}
\hline \multirow{2}{*}{$\begin{array}{l}\text { Medium } \\
\text { concentration } \\
\text { (mosmol) }\end{array}$} & \multirow{2}{*}{$\begin{array}{l}\text { No. of } \\
\text { oocytes } \\
\text { cultured }\end{array}$} & \multicolumn{4}{|c|}{ No. in meiosis I (\%) } & \multirow{2}{*}{$\begin{array}{l}\text { No. in } \\
\text { meiosis } \\
\text { II (\%) } \dagger\end{array}$} & \multirow{2}{*}{$\begin{array}{c}\text { No. } \\
\text { degenerate } \\
\text { and } \\
\text { others (\%) }\end{array}$} \\
\hline & & Dictyate & Prophase & Metaphase & Total* & & \\
\hline 230 & 49 & $13(27)$ & $9(18)$ & $6(12)$ & $28(57)$ & $18(37)^{\mathrm{a}}$ & $3(6)$ \\
\hline 250 & 55 & $7(13)$ & $2(4)$ & $6(11)$ & $16(29)$ & $35(64)^{\mathrm{b}}$ & $4(7)$ \\
\hline 270 & 53 & $9(17)$ & $4(8)$ & $3(6)$ & $16(30)$ & $36(68)^{b}$ & $1(2)$ \\
\hline 290 & 55 & $8(15)$ & $0(0)$ & $4(7)$ & $12(22)$ & $35(64)^{b}$ & $8(15)$ \\
\hline 310 & 48 & $9(19)$ & $1(2)$ & $0(0)$ & $10(21)$ & $31(65)^{b}$ & $7(15)$ \\
\hline 330 & 51 & $6(12)$ & $8(16)$ & $5(10)$ & $19(37)$ & $24(47)^{\mathrm{a}}$ & $8(16)$ \\
\hline 350 & 52 & $16(31)$ & $11(21)$ & $4(8)$ & $32(62)$ & $8(15)^{\mathrm{c}}$ & $12(23)$ \\
\hline
\end{tabular}

Values in parentheses are percentages. Values for meiosis II with different superscripts are significantly different, $P<0.05$.

* One oocyte in the 250 mosmol medium was in telophase I and one oocyte in the 350 mosmol medium was in anaphase $\mathrm{I}$.

$\dagger$ Most oocytes that developed past meiosis I were in metaphase II. 
fluids, and that may alter the osmotic gradient or the salt requirement of cells. Brinster (1965a) noted this in his studies with mouse embryos. Jones \& Foote (1972) found that increasing the concentration of the macromolecular component of media for preserving bull spermatozoa rendered these cells less sensitive to changes in osmolality of the media.

In the present study rabbit oocyte development was similar over a considerable range of salt concentrations (250-310 mosmol). This may indicate that the remaining cumulus cells, which are tightly attached to the rabbit oocyte, afforded some protection. However, McGaughey (1977) found that denuded pig oocytes underwent maturation in media with calculated osmolalities of 265-305 mosmol.

Outside the range of 250-310 mosmol, development of oocytes was retarded considerably. In the hyperosmotic media there tended to be a higher proportion of degenerate oocytes with irregular chromosomal morphology and/or a more transparent amorphous cytoplasm. Extremes in osmotic pressure of the media have previously been observed to induce cytological changes in fertilized mouse eggs. Graham \& Deussen (1974) reported that low osmolarity caused cleavage without cytokinesis, suppressed second polar body formation and caused lysis. Lysis is a characteristic of most cells exposed to severely hypotonic solutions, as a result of swelling to a greater volume than can be accommodated by surrounding membranes. Graham \& Deussen (1974) reported that reducing the $\mathrm{Na}^{+}$and $\mathrm{K}^{+}$concentrations only, while keeping other characteristics of the medium constant, suppressed second polar body formation. Mouse eggs exposed to hypotonic solutions exhibit shrinkage as water is lost to equalize the osmolarity of the intra- and extra-cellular components (Kaufman \& Surani, 1974). Kaufman \& Surani (1974) also reported that the first cleavage mitosis was delayed in hypotonic media. This event was associated with a reduced protein synthesis, or possibly in the kind of protein produced. By altering the osmolality of the medium a variety of parthenogenomes can be produced (Graham \& Deussen, 1974; Kaufman \& Surani, 1974; Opas, 1977). Whether or not these alterations or lack of development result simply from altering the osmotic pressure of the medium, or from imbalances among the multiple components, remains to be tested. A major point of the present study is that the centre of the optimal range of osmolalities for culturing rabbit oocytes is below the osmolality of blood sera.

We thank Dr E. A. B. Oltenacu and Mr Michael Simkin for technical assistance. This study was supported in part by a fellowship from the Population Council (I.-H.B.).

\section{References}

Bae, I.-H. \& Foote, R.H. (1975) Carbohydrate and amino acid requirements and ammonia production of rabbit follicular oocytes matured in vitro. Expl Cell Res. 91, 113-118.

Brinster, R.L. (1965a) Studies on the development of mouse embryos in vitro. I. The effect of osmolarity and hydrogen ion concentration. J. exp. Zool. 158, 49-57.

Brinster, R.L. (1965b) Studies on the development of mouse embryos in vitro. II. The effect of energy source. J. exp. Zool. 158, 59-68.

Cross, P.C. \& Brinster, R.L. (1970) In vitro development of mouse oocytes. Biol. Reprod. 3, 298-307.

Graham, C.F. \& Deussen, Z.A. (1974) In vitro activation of mouse eggs. J. Embryol. exp. Morph. 31, 497-512.

Gwatkin, R.B.L. \& Haidri, A.A. (1973) Requirements for the maturation of hamster oocytes in vitro. Expl Cell Res. 76, 1-7.

Jones, R.C. \& Foote, R.H. (1972) Nondialyzable skim- milk in diluents for ram and bull semen. J. Dairy Sci. 55, 856-861.

Kaufman, M.H. \& Surani, M.A.H. (1974) The effect of osmolarity on mouse parthenogenesis. J. Embryol. exp. Morph. 31, 513-526.

McGaughey, R.W. (1977) The maturation of porcine oocytes in minimal defined culture media with varied macromolecular supplements and varied osmolarity. Expl Cell Res. 109, 25-30.

Naglee, D.L., Maurer, R.R. \& Foote, R.H. (1969) Effect of osmolarity on in vitro development of rabbit embryos in a chemically defined medium. Expl Cell Res. 58, 331-333.

Opas, J.J. (1977) Effect of extremely low osmolarity on fertilized mouse eggs. J. Embryol. exp. Morph. 37, 65-77.

Steel, R.G.D. \& Torrie, J.H. (1960) Principles and Procedures of Statistics, pp. 109-110. McGraw-Hill Book Co., Inc., New York.

Received 13 June 1979 